\title{
UJI POTENSI ANTIDIARE Lactobacillus sp INDIGENOUS SEBAGAI KULTUR STARTER PADA YOGURT DENGAN SUPLEMENTASI EKSTRAK UBI JALAR UNGU
}

\section{EVALUATION OF ANTIDIARRHEAL POTENTIAL OF INDIGENOUS Lactobacillus sp IN PURPLE SWEET POTATO EXTRACT YOGURT}

\author{
Intan Niken Tari, Catur Budi Handayani ${ }^{1}$ \\ ${ }^{1}$ Program Studi Teknologi Hasil Pertanian Universitas Veteran, Bantara, Sukoharjo \\ Email: intanniken@gmail.com
}

\begin{abstract}
The objective of this study was to evaluate the anti-diarrheal properties of Lactic Acid Bacteria (LAB) in yogurt which was supplemented with purple sweet potato qualitatively and quantitatively for one week of storage. The treatment was followed as: SO = Control (commercial culture as Lactobacillus bulgaricus (Lb) Streptococcus thermophilus (St), S1 = probiotic culture Lactobacillus plantarum commercial + Dad 13, namely St: Lb: Dad $13=1: 1: 0.5, S 2=+$ probiotic culture Lactobacillus plantarum commercial Mut7, namely St: Lb: Mut7 = 1: 1: 0.5, S3 = + commercial probiotic cultures Lactobacillus acidophilus SNP-2, namely St: Lb: SNP-2 =1: 1: 0.5. The results showed that the antidiarrheal activity qualitatively indigenous Lactobacillus sp ATCC 35281 against EPEC occurred on treatment Y1 (yogurt with probiotic Lactobacillus plantarum Dad 13 and supplementation of purple sweet potato extract) with inhibition zone diameters of 12, 8 mm. Antidiarrheal activity of Lactobacillus plantarum quantitatively indigenous sp ATCC 35281 against EPEC largest storage for one week, also occurred in the treatment of Y1 (yogurt with probiotics Llactobacillus Dad plantarum 13 and supplementation of purple sweet potato extract) with the ability to decrease the number of colonies EPEC ATCC 35281 by $5 \log$ cycles (from 1.05 initially. $107 \mathrm{CFU} / \mathrm{ml}$ to 8.5. $102 \mathrm{CFU} / \mathrm{ml}$ ).
\end{abstract}

Keywords: Yogurt, Purple Sweet Potato Extract, anti-diarrheal, Lactobacillus sp Indigenous

\begin{abstract}
ABSTRAK
Penelitian ini dilakukan dengan tujuan melihat trend sifat anti diare baik secara kualitatif maupun secara kuantitatif dari BAL pada yogurt dengan suplementasi ubi jalar ungu selama satu minggu penyimpanan. Adapun perlakuan tersebut sebagai berikut : S0=Kontrol ( berupa kultur komersial St dan Lb, $S 1=$ Kultur komersial + probiotik Lactobacillus plantarum Dad 13, yaitu St : Lb : Dad 13= 1:1:0.5, S2= Kultur komersial + probiotik Lactobacillus plantarum Mut7, yaitu St : Lb : Mut7 = 1:1:0.5, S3= Kultur komersial+ probiotik Lactobacillus acidophilus SNP-2 yaitu $S t:$ Lb : SNP-2 = 1:1:0.5. Hasil penelitian menunjukkan bahwa aktifitas antidiare secara kualitatif lactobacillus sp indigenous terhadap EPEC ATCC 35281 terbesar terjadi pada perlakuan Y1 (yogurt dengan probiotik lactobacillus plantarum Dad 13 dan suplementasi ekstrak ubi jalar ungu) dengan diameter zona hambat sebesar 12,8 mm. Aktifitas antidiare secara kuantitatif lactobacillus plantarum sp indigenous terhadap EPEC ATCC 35281 selama 1minggu penyimpanan terbesar, juga terjadi pada perlakuan Y1 (yogurt dengan probiotik Llactobacillus plantarum Dad 13 dan suplementasi ekstrak ubi jalar ungu) dengan kemampuan penurunan jumlah koloni EPEC ATCC 35281 sebesar 5 log cycle (dari mulamula 1,05. $10^{7} \mathrm{CFU} / \mathrm{ml}$ menjadi 8,5.102 $\mathrm{CFU} / \mathrm{ml}$ )
\end{abstract}

Kata kunci: yogurt, ekstrak ubi jalar ungu, anti diare, Lactobacillus sp Indigenous

\section{PENDAHULUAN}

Penyakit infeksi saluran pencernaan masih merupakan salah satu masalah utama di Indonesia. Penyakit infeksi saluran pencernaan yang sering menyerang penduduk ini tergolong penyakit menular maupun penyakit karena keracunan makanan, seperti diare. Di Kabupaten Sukoharjo data angka kesakitan diare pada 2 tahun terakhir menunjukkan peningkatan cukup nyata, yaitu lebih dari 1500 anak usia Sekolah Dasar menderita penyakit diare selama periode tahun 2011/2012 (Anonim a,b, 2012) menjadi 1800 anak usia Sekolah Dasar menderita penyakit diare selama periode tahun 2012/2013 (Anonim ${ }^{\text {c,d }}$, 2013).

Kelompok E. coli yang dikenal sebagai penyebab diare dikenal sebagai Enteropatogenic Escherichia coli (EPEC) dan Enterotoxin Escherichia coli (ETEC). Disebutkan oleh Acheson (1999), bahwa Enteripatogenic Escherichia coli (EPEC) umumnya menyebabkan diare pada anak- 
anak. Kelompok bakteri ini menyebabkan diare melalui interaksi fisik dengan sel epitelium pada dinding usus halus. Kelompok bakteri ini menempel dan menyebabkan pengaruh beracun lipopolisakarida dinding sel (endotoksin) dan menyebabkan luka sel epitelium dinding usus halus, sehingga dinding usus mengalami peradangan dan kehilangan cairan.

Upaya pencegahan infeksi oleh E. coli yang bersifat pathogen dapat dilakukan dengan cara menekan pertumbuhan E.coli . Pertumbuhan E. coli pada saluran pencernaan dapat ditekan jika terdapat keseimbangan mikrobiota dalam saluran pencernaan. Untuk mempertahankan keseimbangan mikrobiota di dalam saluran pencernaan diperlukan pengaturan diet yang mengandung prebiotik, probiotik atau kombinasi keduanya yang disebut sinbiotik.

Konsumsi yogurt dengan suplementasi prebiotik seperti ubi jalar ungu ditengarai memberi manfaat besar bagi kesehatan tubuh. Oligosakarida pada ubi jalar sebagian besar terdiri dari rafinosa dan stakhiosa yang tidak dapat dicerna, namun akan difermentasi oleh bakteri-bakteri yang terdapat dalam usus besar dan selanjutnya akan mengubah komposisi bakteri usus yang menguntungkan (Lactobacillus sp dan Bifidobacterium), dengan cara meningkatkan viabilitas atau kemampuan hidup dalam sistem pencernaan (Wardani, 2003). Selain itu menurut Wang (2009), prebiotik dapat memperbaiki efek perlindungan usus besar terhadap berbagai mikroorganisme pathogen usus .

Menurut Parvez dkk., (2006) bakteri probiotik bermanfaat meningkatkan sistem kekebalan tubuh dan mempunyai efek kesehatan, seperti mengurangi kejadian lactose intolerance, mencegah hipertensi, dan mempunyai efek terapeutik melawan diare. Mekanisme probiotik dalam mengatur mikroflora saluran pencernaan antara lain akibat adanya kompetisi dengan mikroflora usus. Produksi senyawa antibakteri seperti bakteriosin untuk mengontrol pertumbuhan mikroflora lainnya, produksi senyawa asaml aktat dan asam-asam lainnya sehingga $\mathrm{pH}$ turun dan mengatur aktiviats enzim. (Commane dkk., 2005)
Menurut Codex persyaratan jumlah sel hidup probiotik dalam susu fermentasi minimal $10^{7} \mathrm{CFU} / \mathrm{g} \quad$ (Anonymous, 2008), diharapkan dapat mengantisipasi penurunan jumlah sel selama melewati lingkungan ekstrem di pencernaan (Shah, 2000).

Astawan (2009) berpendapat bahwa, bakteri asam laktat yang terdapat pada yogurt komersial yaitu Streptococcus thermophillus dan Lactobacillus bulgricus belum cukup menjaga saluran pencernaan, sehingga ke dalamnya perlu ditambahkan bakteri probiotik.. Sedangkan beberapa bakteri asam laktat yang telah berhasil diisolasi (isolat indigenous) dan mempunyai sifat probiotik antara lain : Lactobacillus plantarum Dad 13 yang diisolasi dari susu fermentasi kerbau (dadih), Lactobacillus plantarum Mut 7 yang diisolasi dari makanan fermentasi ketela (gatot) serta Lactobacillus acidophillus SNP2 yang disolasi dari feses bayi yang mengkonsumsi asi. Keuntungan dari kombinasi prebiotik dan probiotik (sinbiotik) adalah meningkatkan daya tahan mikroflora saluran pencernaan, sehingga tubuh mendapat manfaat yang lebih sempurna dari kombinasi ini.

Penelitian pendahuluan terhadap pengaruh kultur indigenous Lactobacillus plantarum dalam pembuatan yogurt ubi ungu telah dapat dilakukan, dengan hasil tingkat keasaman 11.956 mgrek/ 100g bahan, $\mathrm{pH}$ 4.378 dan total padatan $13.593 \%$ Niken Tari (2012), namun belum diketahui pengaruh antidiarenya. Penelitian terhadap penggunaan ubi ungu sebagai prebiotik lokal dan Lactobacillus plantarum Dad 13, Lactobacillus plantarum Mut 7, maupun Lactobacillus acidophillus SNP-2 sebagai probiotik lokal perlu dilakukan. Penelitian ini diharapkan dapat memperkaya pemanfaatan produk lokal untuk menciptakan produk pangan dengan bentuk berbeda seperti yogurt dengan substitusi ekstrak ubi ungu menggunakan starter indigenous Lactobacillus plantarum sp, yang mempunyai kemampuan sebagai antidiare.

Tujuan Penelitian ini adalah : (1) Mengetahui pengaruh jenis kultur starter lactobacillus plantarum sp indigenous pada yogurt dengan suplementasiekstrak ubi jalar ungu terhadap potensi antidiare secara 
kualitatif (2). Mengetahui pengaruh jenis kultur starter lactobacillus plantarum $s p$ indigenous pada yogurt dengan suplementasi ekstrak ubi jalar ungu terhadap potensi antidiare secara kuantitatif selama 1 minggu penyimpanan

\section{Bahan dan Alat}

METODE PENELITIAN

Bahan yang digunakan terdiri dari ubi jalar ungu (Ipomoea batatas L) yang diperoleh dari pasar lokal daerah Sukoharjo, kultur bakteri asam laktat koleksi FNCC (Food and Nutrition Culture Collection) dari PAU Pangan dan Gizi UGM Yogyakarta berbentuk agar tegak, terdiri dari Streptococcus thermophillus FNCC 0040 dan Lactobacillus bulgaricus FNCC 0041, serta kultur bakteri asam laktat indigenous yang mempunyai sifat probiotik seperti Lactobacillus plantarum Dad 13, dan Lactobacillus plantarum Mut 7 dan Lactobacillus plantarum SNP-2.

Untuk pemeliharaan kultur bakteri asam laktat, digunakan media MRS (de Mann Rogossa Sharp) Agar/Broth. Bahan-bahan kimia penunjang pembuatan prebiotik ubi jalar ungu melalui fermentasi laktat seperti,sukrosa, skim serta bahan kimia penunjang lain seperti alkohol $70 \%$, spiritus, dan aquades diperoleh dari Lab. Biologi-Kimia dan Mikrobiologi Fakultas Pertanian Univet Bantara Sukoharjo.

\section{Tahapan penelitian}

Persiapan-persiapan yang diperlukan pada penelitian ini antara lain :

\section{Pembuatan starter}

Menyiapkan $5 \mathrm{ml}$ medium MRS broth steril sebanyak 6 tabung, kemudian masingmasing tabung diinokulasi dengan biakan tegak Lactobacillus bulgaricus FNCC 0041. Streptococcus thermophilus FNCC 0040, Lactobacillus plantarum Dad 13 dan Lactobacillus plantarum Mut 7 dan Lactobacillus plantarum SNP-2. Kemudian kesemua isolat diinkubasi pada suhu $36^{\circ} \mathrm{C}$ selama 24 jam. Untuk membuat kultur starter, masing-masing $0.1 \mathrm{ml}$ biakan tersebut kemudian diinokulasikan ke dalam $5 \mathrm{ml}$ susu skim steril. Diinkubasi $43^{\circ} \mathrm{C}$ selama $7-8$ jam atau $36^{\circ} \mathrm{C}$ selama 24 jam.

\section{Pembuatan ekstraki ubi jalar ungu}

Pembuatan ekstrak ubi jalar ungu mengacu pada penelitian pendahuluan yang telah dilakukan sebelumnya oleh Niken Tari (2011) yaitu ubi jalar dipotong kecil (ukuran $5 \times 5 \mathrm{~cm}$ ). Ubi jalar kemudian diblanching pada suhu $100^{\circ} \mathrm{C}$ selama $2-3$ menit kemudian diekstrak menggunakan juicer, didiamkan 30 menit kemudian diambil filtratnya. Filtrat ini merupakan ekstrak ubi jalar ungu yang siap digunakan untuk membuat yogurt.

\section{Pembuatan yogurt dengan suplementasi ekstrak ubi jalar ungu}

Susu segar, susu skim $(5 \% \mathrm{~b} / \mathrm{v})$ dan ekstrak ubi jalar ungu $(10 \% \quad \mathrm{v} / \mathrm{v})$ dipasteurisasi pada suhu $75^{\circ} \mathrm{C}$ selama 15 menit, kemudian didinginkan sampai suhu $40-45^{\circ} \mathrm{C} \quad$ selanjutnya, diinokulasi menggunakan Streptococcus thermophillus dan Lactobacillus bulgaricus serta tambahan baketri probiotik indigenous dengan perbandingan 1 :0,5:0,5 yang dilakukan secara aseptis pada suhu $43-45^{\circ} \mathrm{C}$, sebanyak 2,5\% (v/v), kemudian dikocok hingga homogen. Susu dan ekstrak ubi jalar ungu yang telah diinokulasi dengan starter tadi,dimasukkan ke dalam botol-botol steril dan diinkubasi pada suhu $40^{\circ} \mathrm{C}$ selama 17 jam, hingga dihasilkan yogurt dengan suplementasi ekstrak ubi jalar ungu

\section{Rancangan Percobaan}

Penelitian ini dilakukan dengan rancangan acak lengkap pola searah (RAL), dengan 4 macam perlakuan yaitu jenis BAL dan masing-masing perlakuan diulang 3 kali. Adapun perlakuan tersebut sebagai berikut : $\mathrm{S} 0=$ Kontrol ( berupa kultur komersial St dan $\mathrm{Lb}, \mathrm{S} 1=$ Kultur komersial + probiotik Dad 13, yaitu St : Lb : Dad 13=1:1:0.5, S2= Kultur komersial + probiotik Mut7, yaitu St : Lb : Mut7 = 1:1:0.5, S3= Kultur komersial+ probiotik SNP-2 yaitu St : Lb : SNP-2 = $1: 1: 0.5$ 

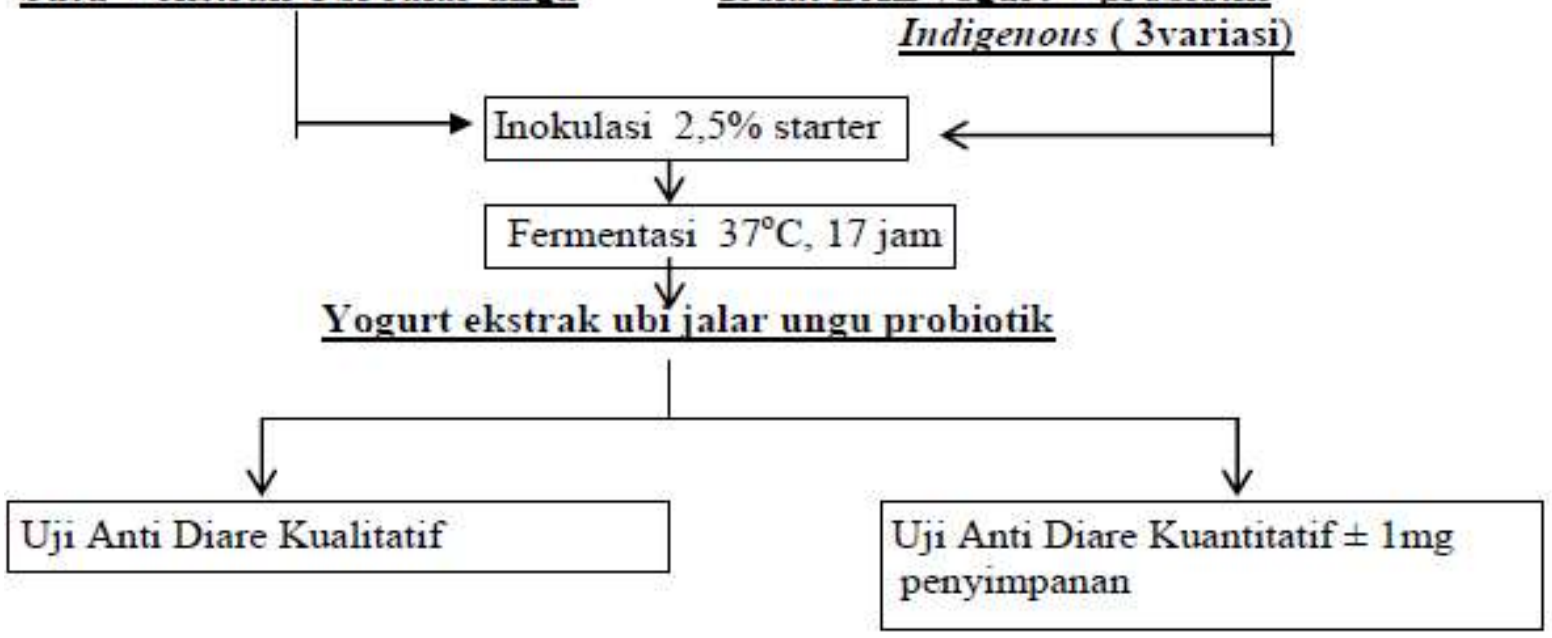

Gambar 1. Diagram alir alur penelitian

\section{Parameter Pengujian}

Parameter pengujian yang dilakukan terdiri atas : (1) uji aktivitas anti diare secara kualitatif dan (2) uji aktivitas anti diare secara kuantitatif selama 1minggu penyimpanan.

\section{Uji aktivitas anti diare secara kualitatif} selama 1 minggu penyimpanan

Bakteri pathogen yang digunakan dalam penelitian ini adalah Escherichia coli enteropathogenic (EPEC). Prosedur pengujiannya dilakukan dengan metode difusi agar. Satu ose kultur E.coli diinokulasikan dalam media NB (Nutrient Broth) $20 \mathrm{ml}$ dan diinkubasi $30^{\circ} \mathrm{C}$ selama 24 jam. Bakteri E.coli kemudian diinokulasikan sebanyak $25 \mu 1$ ke dalam NA (Nutrient Agar), kemudian divortek. Setelah tercampur merata kemudian dituang ke dalam petridish steril secara pour plate dan dibiarkan mengeras. Media NA yang telah mengeras kemudian dibuat sumuran dengan alat bor steril pada $1 / 4$ bagian tengah cawan petri. Sumuran yang telah dibuat pada media NA diisi dengan yogurt sesuai perlakuan. Kemudian diinkubasi $37^{\circ} \mathrm{C}$ selama 24 jam. Diameter zona bening yang terbentuk sekitar sumuran diukur sebagai zona penghambatan Lactobacillus $s p$ terhadap bakteri E. coli enteropathogenik. Uji aktivitas antidiare secara kualitatif ini dilakukan pada minggu ke 0 dan minggu ke 1 setelah penyimpanan yogurt

\section{Uji aktivitas anti diare secara kuantitatif} selama 1 minggu penyimpanan

Aktivitas antidiare BAL terhadap patogen E.coli enteropatogenik secara kuantitatif dengan metode kontak langsung. Sebanyak $0,1 \mathrm{ml}(1 \%)$ kultur bakteri pathogen dimasukkan ke dalam $10 \mathrm{ml}$ produk untuk mengetahui jumlah E.coli awal (jam ke 0), maka dilakukan platting dengan media spesifik EMBA pada tingkat pengenceran produk $10^{-6}, 10^{-7}$ dan $10^{-8}$ kemudian dilakukan inkubasi $37^{\circ} \mathrm{C}$ selama $24-48 \mathrm{jam}$.

Sementara itu, untuk mengetahui seberapa besar penghambatan formula yogurt, maka bakteri E. coli (1\%) dikontakkan dengan masing-masing formula yogurt selama \pm 2 jam. Penentuan lama waktu kontak tersebut merupakan waktu bakteri E. coli berada pada fase log (Quigley, 2008).

Setelah itu, jumlah bakteri E.coli akhir dapat diketahui dengan melakukan platting masing-masing formula yang telah ditarungkan dengan E.coli pada media EMBA dan diinkubasi pada suhu $37^{\circ} \mathrm{C}$ selama 24 jam.Efek penghambatan masing-masing formula yogurt dapat diketahui dengan mengurangi jumlah E.coli awal dan E.coli akhir. 


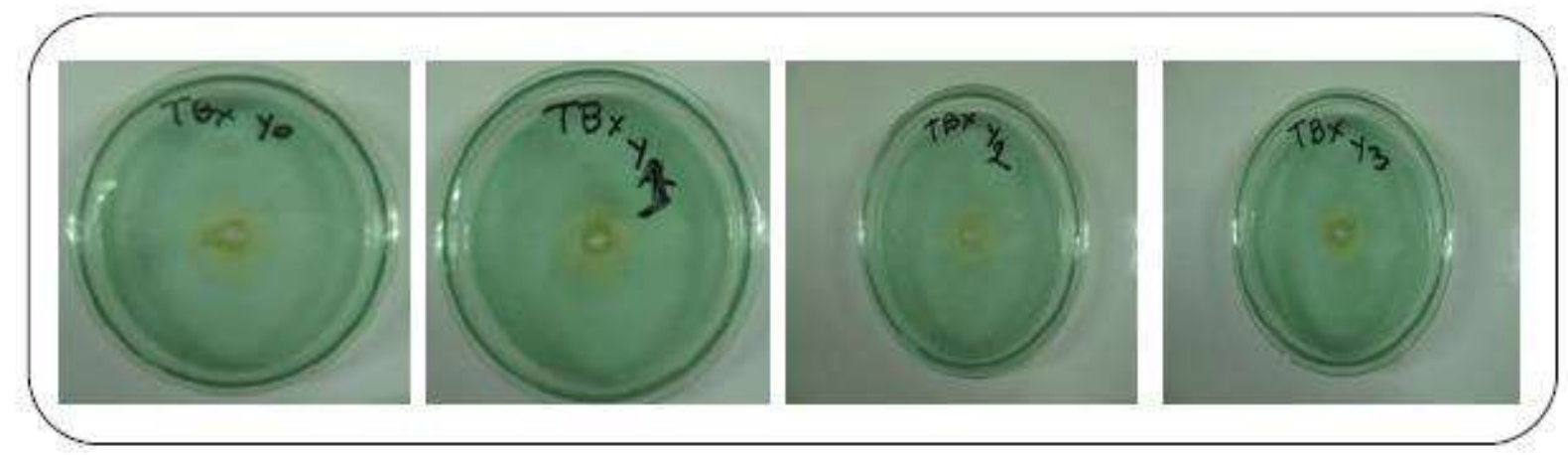

Gambar 2. Pengukuran Aktivitas Antidiare Bakteri Pro-biotik Indigenous yang Ditambahkan pada Yogut Ekstrak Ubi Jalar Ungu secara Kualitatif (Berdasarkan Diameter Zona Hambat) selama 1 Minggu Penyimpanan (Ket: $\phi \mathrm{Yo}_{\mathrm{o}}=12,0 \mathrm{~mm}, \mathrm{Y} 1=12,8 \mathrm{~mm}, \mathrm{Y} 2=$ $12,3 \mathrm{~mm}$ dan $\mathrm{Y} 3=12,5 \mathrm{~mm}$

\section{HASIL DAN PEMBAHASAN}

\section{Uji aktivitas anti diare secara kualitatif selama 1 minggu penyimpanan}

Aktifitas anti diare BAL probiotik indigenous yang ditambahkan pada yogurt dengan suplementasi ekstrak ubi jalar ungu dilakukan uji pendahuluan dengan mengamati zona hambat antibakteri atau antidiare yang dihasilkan terhadap pertumbuhan bakteri Enteropathogenic Escherichia coli (EPEC) ATCC 35218. Hasil uji daya hambat antidiare BAL probiotik indigenous yang ditambahkan pada yogurt dengan suplementasi ekstrak ubi jalar ungu terhadap EPEC ATCC 35218 dapat dilihat pada Tabel 2 dan Gambar 3.

Tabel 1 dan Gambar 2 menunjukkan zona penghambatan antimikrobia (antidiarea) BAL indigenous pada yogurt dengan suplementasi ekstrak ubi jalar ungu terhadap EPEC ATCC 35218.

Tabel 1. Hasil Uji Daya Hambat Antimikrobia BAL Indigenous pada Yogurt dengan Suplementasi Ekstrak Ubi Jalar Ungu terhadap EPEC ATCC 35218

\begin{tabular}{cc}
\hline Perlakuan & $\begin{array}{c}\text { Diameter Zona } \\
\text { Hambat }(\mathrm{mm})\end{array}$ \\
\hline Y0 & 12,0 \\
Y1 & 12.8 \\
Y2 & 12,3 \\
Y3 & 12,5 \\
\hline
\end{tabular}

Pada Gambar 3 tersebut dapat dilihat bahwa perlakuan Y1 yaitu yogurt dengan suplementasi ekstrak ubi jalar ungu dengan penambahan probiotik Lactobacilus plantarum Dad 13 yang berasal dari dadih menunjukkan zona hambat paling besar sebesar 12, $8 \mathrm{~mm}$ diikuti Y3 (yogurt dengan suplementasi ekstrak ubi jalar ungu dengan penambahan probiotik Lactobacilus acidophilus SNP2 yang berasal dari feses bayi ASI), Y2 (yogurt dengan suplementasi ekstrak ubi jalar ungu dengan penambahan probiotik Lactobacilus plantarum Mut7 yang berasal dari growol) dan Y0 (yogurt dengan suplementasi ekstrak ubi jalar ungu tanpa penambahan probiotik) masing-masing dengan diameter zona hambat $=12,5 \mathrm{~mm}$, $12,3 \mathrm{~mm}$ dan $12,0 \mathrm{~mm}$.

Menurut Davis dan Stout (1971) dalam Maunatin dkk.(2012) aktivitas antibakteri suatu bakteri ditentukan berdasarkan diameter zona hambat bakteri tersebut terhadap bakteri indikator yang umumnya berupa bakteri pathogen, dengan kisaran $>20$ $\mathrm{mm}=$ sangat kuat, $10-20 \mathrm{~mm}=$ kuat, $5-10$ $\mathrm{mm}=$ sedang dan $<5 \mathrm{~mm}=$ lemah. Dari data di atas, ternyata bakteri probiotik indigenous yang ditambahkan pada yogurt dengan sulementasi ekstrak ubi jalar ungu mempunyai zona penghambatan rata-rata kuat (12,0-12,8 mm).

Menurut Ray (1996), sensitivitas suatu bakteri indikator yang umumnya berupa bakteri pathogen terhadap substrat antimikrobia dipengaruhi oleh lapisan peptidoglikan yang menyusun dinding sel. Peptidoglikan bakteri Gram negatif hanya 1$2 \%$ dari berat kering sel dibandingkan dengan peptidoglikan Bakteri Gram positif yang mencapai $20 \%$ berat kering sel. Namun 
karena bakteri Gram Negatif mempunyai membran luar yang tersusun atas lipoprotein sebesar $30 \%$, fosfolipid $40-45 \%$ dan protein $40-45 \%$ maka bakteri Gram negatif lebih mampu bertahan terhadap lingkungan luar seperti senyawa antibakteri. EPEC ATCC 35218 merupakan bakteri pathogen Gram negatif yang mempunyai lapisan peptidoglikan tipis namun relatif tahan terhadap kerusakan mekanis terhadap senyawa antimikrobia BAL, sehingga ratarata daya hambat dari $\mathrm{BAL}$ indigenous yang ditambahkan pada yogurt dengan suplementasi ekstrak ubi jalar ungu mempunyai diameter antara 12,0-12,8 mm dengan kategori kuat.

\section{Uji Aktivitas Anti Diare Secara Kuantitatif Selama 1 Minggu Penyimpanan}

Kemampuan anti diare Bakteri Asam Laktat yang terdapat pada yogurt dengan suplementasi ekstrak ubi jalar ungu dilakukan dengan mempertarungkan antara Bakteri Asam Laktat yang terdapat pada yogurt dengan suplementasi ekstrak ubi jalar ungu pada berbagai perlakuan dengan Enteropathogenic Escherichia coli (EPEC) ATCC 35218, menggunakan media TBX sebagai media selektif pertumbuhan E.coli Pengamatan dilakukan dengan mengamati trend penurunan total E.coli selama 0 dan 1 minggu penyimpanan.

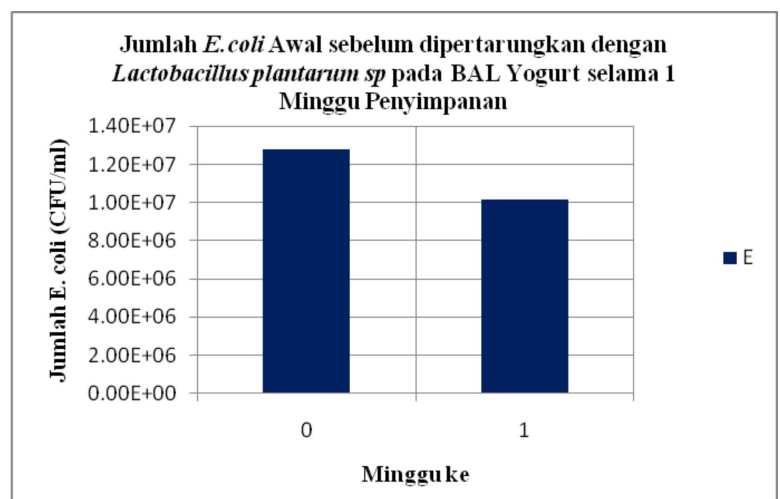

Gambar 3. Jumlah EPEC ATCC 35218 (CFU/ml) Selama 1 minggu Penyimpanan

Aktifitas antidiare BAL yogurt dengan suplementasi ekstrak ubi jalar ungu, dihitung sebagai pengurangan jumlah $E$. coli mulamula (CFU/ml) terhadap jumlah E.coli setelah ditarungkan dengan BAL yang ada pada masing-masing perlakuan yogurt dengan suplementasi ekstrak ubi jalar ungu selama 1 minggu penyimpanan (CFU/ml). Pengujian antidiare menggunakan EPEC (Enteropathogenic Escherichia coli ATCC 35218) dikarenakan bakteri ini sering menginfeksi timbulnya penyakit yang menyerang saluran pencernaan baik pada manusia maupun hewan serta sensitif terhadap antimikrobia (antidiare) yang dihasilkan BAL . Pada Gambar 3. terlihat bahwa jumlah koloni E.coli mula-mula selama 1 minggu penyimpanan rata-rata $10^{7}$ $\mathrm{CFU} / \mathrm{ml}$.

Pada Gambar 3 dapat dilihat bahwa saat awal penyimpanan yaitu minggu ke 0 atau 4 jam pertama setelah Enteropathogenic Escherichia coli ATCC 35218 dipertarungkan dengan BAL indigenous yang ada pada yogurt dengan penambahan ekstrak ubi jalar ungu, jumlah Enteropathogenic Escherichia coli ATCC 35218 rata-rata mengalami penurunan $2 \mathrm{log}$ cycle atau $10^{5} \mathrm{CFU} / \mathrm{ml}$ pada semua perlakuan baik pada Y0, Y1, Y2 maupun Y3.

Pada Gambar 4 juga dapat dilihat bahwa setelah 1 minggu penyimpanan, jumlah Enteropathogenic Escherichia coli ATCC 35218 menurun $3 \log$ cycle yaitu menjadi $10^{4}$ $\mathrm{CFU} / \mathrm{ml}$ dan $6,25.10^{4} \mathrm{CFU} / \mathrm{ml}$, masingmasing setelah ditarungkan dengan BAL yang ada pada yogurt dengan penambahan ekstrak ubi jalar ungu pada perlakuan Y0, (yogurt dengan penambahan ekstrak ubi jalar ungu tanpa probiotik) dan Y3 (yogurt dengan penambahan ekstrak ubi jalar ungu dan penambahan probiotik Lactobaciluus acidophilus SNP2 yang berasal dari feses bayi yang menkonsumsi ASI). Jumlah Enteropathogenic Escherichia coli ATCC 35218 mengalami penurunan paling besar sebanyak 5 log cycle yaitu menjadi $8,5.10^{2}$ $\mathrm{CFU} / \mathrm{ml}$ setelah dipertarungkan dengan BAL pada perlakuan Y1 (yogurt dengan suplementasi ekstrak ubi jalar ungu dan penambahan probiotik Lactobacilus plantarum Dad 13 yang berasal dari dadih), sedangkan jumlah E.coli mengalami penurunan paling kecil ketika dipertarungkan dengan BAL pada yogurt dengan perlakuan Y2 (yogurt dengan suplementasi ekstrak ubi jalar ungu dengan penambahan probiotik 
Lactobacilus plantarum Mut 7 yang berasal dari growol).

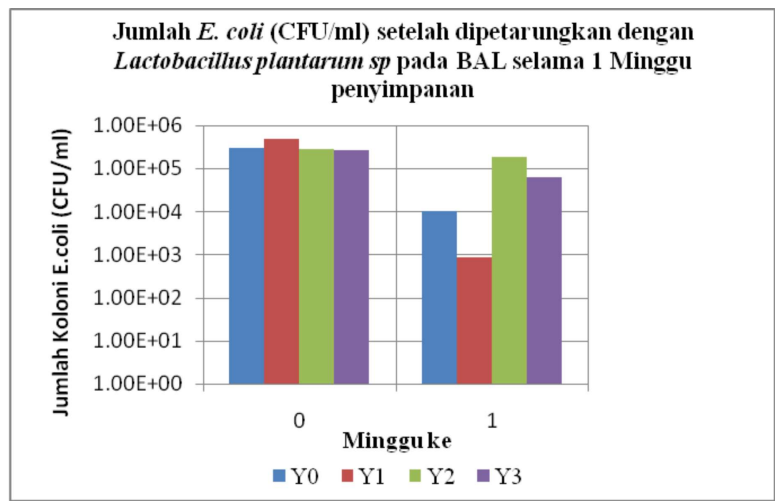

Gambar 4. Jumlah EPEC ATCC 35218 (CFU/ml) setelah dipertarungkan dengan Lactobacilus plantarum sp indigenous pada Yogurt yang disuplementasi Ubi Jalar Ungu selama 1 Minggu Penyimpanan .

Kemampuan mikrobia probiotik BAL indigenous pada perlakuan $\mathrm{Y} 1, \mathrm{Y} 2$ maupun Y3 dalam menekan pertumbuhan bakteri pathogen EPEC ATCC 35218 disebabkan karena kemampuannya untuk memproduksi senyawa antimikrobia sebagai metabolit primer seperti asam laktat dan asam asetat, hidrogen peroksida dan dengan menghasilkan bakteriosin yang merupakan senyawa protein yang menunjukkan aktivitas antibakteri terhadap bakteri sejenis. Akumulasi senyawa tersebut di dalam sel terjadi karena BAL probiotik tersebut tidak menghasilkan enzim katalase (Salminen dan Wright, 1993).

\section{KESIMPULAN}

Dari Hasil penelitian dapat disimpulkan bahwa : (1).Aktivitas antimikrobia atau antidiare BAL indigenous yang ditambahkan pada yogurt dengan suplementasi ekstrakubi jalar ungu, secara kualitatif dapat diamati dari besarnya zona hambat (clear zone) yang dihasilkan terhadap bakteri indikator EPEC ATCC 35218. (2).Besarnya zona hambat BAL indigenous yang ditambahkan pada yogurt dengan suplementasi ekstrakubi jalar ungu berturut-turut adalah Y1, Y3,Y2 dan Y0 masing-masing dengan diameter zona hambat sebesar $12,8 \mathrm{~mm}, 12,5 \mathrm{~mm}, 12,3 \mathrm{~mm}$ dan $12,0 \mathrm{~mm}$ (3). Selama 1 minggu penyimpanan, aktivitas antidiare BAL indigenous yang ditambahkan pada yogurt dengan suplementasi ekstrak ubi jalar ungu mampu menurunkan EPEC ATCC 35218 sebesar 5 log cycle pada perlakuan Y1, diikuti Y3 dan Y0 sebesar $3 \log$ cycle dan Y 2 sebesar $2 \log$ cycle.

\section{DAFTAR PUSTAKA}

Acheson, D. 1999. Escherichia coli. Food Quality. Vol. 51 N0. 10: 44-46

Andriani,MAM dan LU Khasanah. 2009. Kajian Karaktristik Fisiko Kimia dan Sensori Yogurt dengan Penambahan Ekstrak Ubi Jalar (Ipomoea batatas L). Artikel Ilmiah Penelitian Universitas Sebelas Maret. Surakarta

Anonim. 2012. Laporan Tahunan Angka Kesakitan Diare Rumah Sakit Umum Sayang Ibu dan Anak "DKR" Sukoharjo. Sukoharjo. - Laporan Tahunan Angka

Kesakitan Diare Rumah Sakit Umum "Dr. Oen" Solo Baru. Sukoharjo.

Anonim. 2013. Laporan Tahunan Angka Kesakitan Diare Rumah Sakit Umum Sayang Ibu dan Anak "DKR" Sukoharjo. Sukoharjo. - Laporan Tahunan Angka

Kesakitan Diare Rumah Sakit Umum "Dr. Oen" Solo Baru. Sukoharjo.

Anonim. 1989. Microbes in the Intestine; Our Lifelong Partners. Yakult Honsa, Co. Ltd. Tokyo.

Anonymous. $2008 \quad$ http :/ www.codexalimentarius.com/codex stan 243-2003

Astawan, M dan Andreas Leomitro Kasih. 2008. Khasiat Warna-warni Makanan.

PT Gramedia Pustaka Utama. Jakarta

Commane D, R Hughes, C. Shortt, I. Rowland. 2005. The Potensial Mechanisms Involved In The Anticarcinogenic Action Of Probiotics. Mutation Research 591 : 276-289

Maunatin, Anik dan Khanifa. 2012. Uji Potensi Probiotik Lactobacillus plantarum Secara In-Vitro. Alchemy Vol 2 No. 1: 26-34

Niken Tari, A. I..Catur Budi Handayani, Ahimsa Kandi Sariri. 2012. Pengaruh Kultur Indigenous Lactobacillus sp 
dalam Pembuatan Yogurt Ubi Ungu : Salminen S, Von Wright A, dan Ouwehand Kajian Tingkat Keasaman, $\mathrm{pH}$ dan Total Padatannya. Jurnal Teknologi A. 2004. Lactic acid Bacteria. New York: marcel Dekker,Inc

Hasil Pertanian UNS.ISSN : 1979-0309 Vol Nol Maret 2012

Parvez S., Malik, K.A., Ah Kang,S and Kim,H.Y. 2006. Probiotics and Their Fermented Food Products are Beneficial for Health. Review article.J. Appl. Microbio. 100 : 1171-1185

Ray, B. 1996. Fundamental Food Wardani, H.E. 2003. Pengaruh Kombinasi Oligosakarida dengan Lactobacillus sp terhadap Fraksi Lipid Serum Tikus Hiperkolesterolemia. Abstrak Penelitian Pusat Kesehatan Lingkungan. Universitas Diponegoro Semarang

Microbiology. CRC Press.Boca Raton

New York London, Tokyo 